\title{
Investigation of Resource Distribution Based on the Relationship Between Accident Regions and Accident Types
}

\author{
Alper Kilic*, Emrah Akdamar \\ Maritime Faculty, Bandirma Onyedi Eylul University, Bandirma 10200, Turkey
}

Corresponding Author Email: alperkilic@bandirma.edu.tr

https://doi.org/10.18280/ijsse.100607

Received: 24 October 2020

Accepted: 10 December 2020

\section{Keywords:}

maritime safety, marine accidents, accident prevention, correspondence analysis, resource distribution

\begin{abstract}
The aim of this study is to investigate the relationship between accident types and the regions where the accidents occur, and to examine whether the resources required for accident prevention are distributed appropriately in the accident regions. In the study, the relationship between seven different types of accidents that occurred in seven different regions between the years of 2001-2016 was analyzed through the correspondence analysis. This analysis has been preferred because of its successful applications in various studies on accidents in the literature. As a result of the study, a significant relationship was found between accident types and accident regions, which means accident types vary by regions and there are accident types specific to accident regions. Collision in the Istanbul, grounding in the Canakkale and capsize accidents in the Izmir were determined to be more frequent. These findings are consistent with previous studies. It has been observed that, among regions, there are some imbalances in the distribution of resources used for marine accident response.
\end{abstract}

\section{INTRODUCTION}

In maritime transport, accidents such as collisions, groundings, contacts, oil spills, and fires occur constantly and often cause serious consequences [1]. There are various organizations that examine marine accidents in different regions around the world [2-10]. In Turkey, maritime accidents are monitored by the Search and Rescue Coordination Center established under the Ministry of Transport and Infrastructure, in accordance with International Convention on Maritime Search and Rescue (SAR-1979) [11].

Regarding accidents at sea in the literature, most studies have focused on the marine accident risks involved [12-17]. In this study, the relationship between the types of marine accidents and the regions where the accidents occurred is investigated. Among the parameters that differentiate the regions from each other are meteorology, sea structure, sea traffic, ship types and sizes, the profile of the seafarer working on the ships, and the port state controls on the ships. For example, air temperature, which is a meteorological variable, increases the fire risk of cargo according to its flash point. Sea features such as currents and waves can cause ships to drift and run aground. The insufficiency of regional navigation measures, the existence of port facilities in the region, the density of sea traffic arising from cabotage and international transportation increase the risk of collision. The type of cargo carried, the type of ship, the size and age of the ship, substandard ships can increase hull and engine failure in these regions. There may be differences in the inspection of ships between the regions and the preferred class, flag and accordingly the working seaman profile may change according to the regions. Therefore, limited to, a priori relationship is expected between regions and types of marine accidents.

Analysis methods used in researches on marine accidents have changed in the last 50 years. As a result of a comprehensive literature review on these methods, descriptive analysis techniques such as "accident rate calculation" and "descriptive statistics" were used in early studies in marine accident research. Later, these studies continued with case studies and probability calculations such as "basic regression", "cost analysis", "event tree analysis". In recent studies, it is seen that methods such as "Formal Safety Assessment (FSA)", "Bayesian Networks (BN)", "Artificial Neural Networks (ANN)", "Analytic Hierarchical Process (AHP)", "Fuzzy Fault Tree Analysis (FFTA)", "Balanced Score Card (BSC)", "Evidential Reasoning (ER)", "Geographical Information System (GIS)" that require multivariate and multidisciplinary approach are used. Especially after 1995, many studies have adopted econometric methods to find causal factors [18].

The correspondence analysis used in this study is one of the multivariate statistical techniques. This method has two main advantages: the first is that when investigating the relationship between categorical variables, a distribution assumption is not needed for these variables, and the second is that it not only determines the relationships between categorical variables, but also provides visual representation of this relationship. By visualizing the relationship, more detailed inferences can be made about the relationships between categories of variables. It also gives an idea of the strength of the relationship in question.

In this study, all marine accidents in Turkey's territorial waters with a holistic view all along the 16 years between the years 2001-2016 for the first time. The purpose of the study is to examine the relationship between accident types and the regions where the accident occurred, and accordingly, to investigate the suitability of resource distribution used for intervention in accidents in the waters of the region. For this purpose, by using data regarding administrative regions of 
Canakkale, Izmir, Mersin, Samsun, Trabzon, Antalya and Istanbul, seven different accident types, including capsize, collision, fire, grounding, ship loss, dangerous situation and other types of accidents have been studied.

\section{PREVIOUS ACCIDENT STUDIES IN REGION}

Although there are many studies in the literature regarding the regions where the straits are located such as Istanbul and Çanakkale where ship traffic and accidents occur intensely, it has been observed that there are not enough studies on other regions. Accident zones are "Regions" that defined by the Main Search and Rescue Coordination Center located in the administrative region of the territorial waters designated for Turkey. The boundaries of the regions within the data are shown in Figure 1 on the map.

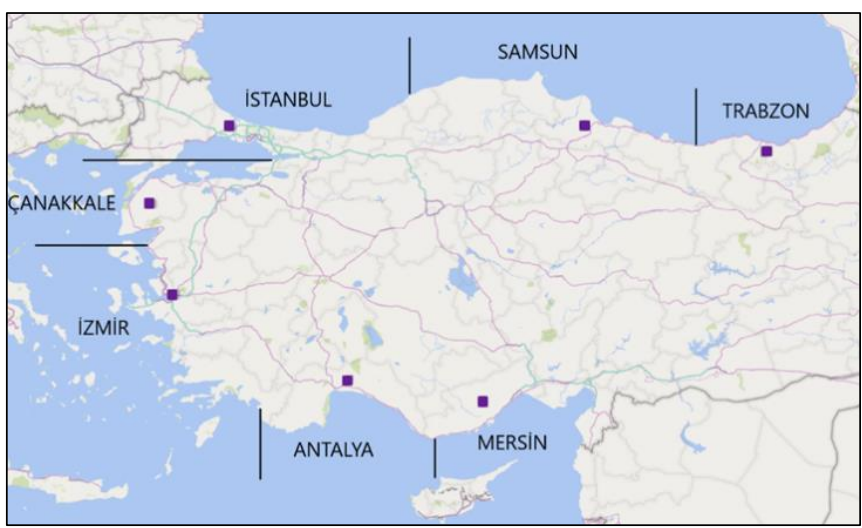

Figure 1. The regions examined in the study and their boundaries

The waterway consisting of the Bosphorus, the Marmara Sea and the Dardanelles is called the Turkish Straits. Turkish Straits is one of the busiest waterways in the world. Pilotage service started to be implemented in 1,856 in order to reduce the risk of accidents in ship crossings through the Turkish Straits [19]. Turkish Straits, due to oceanographic, hydrological and meteorological conditions, it is the second strait where international maritime traffic is the busiest and has navigational risks [20]. Due to various reasons, reverse currents occur and create significant negative effects on the navigation and maneuvering of ships in the Turkish Straits [21]. The width of the Dardanelles Strait varies from $1 \mathrm{~km}$ to $6 \mathrm{~km}$, and the width of the Istanbul Strait varies between 0.7$3.5 \mathrm{~km}$, and ships pass very close to the coastal areas where densely populated areas [22]. There are many important marine accidents in the region causing loss of life, property and environmental [23].

The Bosphorus has had a great importance since very early times in history as a natural canal [24]. In addition to the difficulty of maneuvering due to the narrowness of the Bosphorus, geographical formations such as Bebek bank, Galatasaray Island, Maiden's Tower, Dikilikaya bench and Umuryeri shallow also pose a risk for the navigation of ships. Ships change their routes at least 12 times while crossing the Istanbul Strait, and strong winds adversely affect the maneuvers of ships having high freeboard [25]. The highest risk of accidents in the Bosphorus is Rumeli Hisar1-Anadolu Hisar1 and Ortaköy-Beylerbeyi zones and wrong navigation and machine failure are the main causes of the accident [26]
The region between Kadıköy-Yenikapı and Üsküdar-Beşiktaş zones are the highest local sea traffic in the Bosphorus [27]. Ship traffic in the Bosphorus has a Right Lane Layout since 1982. Most of the accidents that occurred until 2010 were caused by human error. In another study, statistically significant relationships were found between accident typeaccident cause-accident region, ship type-accident type, and ship flag-accident region [28]. Izmit Gulf, located inside the Istanbul Region, is also a region with a high risk of accidents due to the presence of dense industrial facilities and ports. In Izmit Gulf, the most dangerous zone is between Eskihisar and Topcular, where $50 \%$ of the collisions and $80 \%$ of groundings occur in this region [29]. In a study conducted for Mersin Region, it was determined that the existence of ports and facilities in Iskenderun Bay creates a pollution risk on the coasts due to ship accidents [30].

\section{DATA AND METHOD}

\subsection{Data}

Accessing data on marine accidents is a worldwide problem Indeed, the number of accidents by IMO member Flag States are shown less than they are [31]. Regarding maritime accidents, comparing Lloyd's Register FairPlay (LRFP) data with the data of the Flag States shows that the accidents reported by the Flag States are incomplete. Database developers and casualty investigation units need to collaborate to provide a more reliable information service [32]. Underreporting of marine accidents is a problem not only for authorities trying to improve maritime safety through legislation, but also for risk management companies and other organizations that use marine accident statistics in risk and accident analysis. When accident data from IHS Fairplay and some states' maritime authorities are compared, it is seen that the number of unreported accidents accounts for roughly $50 \%$ of all accidents [33]. Because long-term marine accident data is required to estimate regional risk criteria and safety indices, the maritime safety administration or authorities should establish a complete database of ship traffic accidents and accident recording and investigation policy [34].

In this study, data from seven different accident types in seven different regions were used. The data set covers the total number of accidents that occurred between the years of 20012016. Data on marine accidents in Turkish territorial waters are collected by the Ministry of Transport. The accident data used in this study are official data obtained directly from the Ministry. Table 1 shows the data used in the study.

Table 1. Data used in the study [35]

\begin{tabular}{ccccccccc}
\hline & Cs & Cl & Fr & Gr & Sl & Ds & Ot & $\boldsymbol{\Sigma}$ \\
\hline Ist & 88 & 327 & 92 & 138 & 5 & 138 & 74 & 862 \\
Izm & 93 & 40 & 50 & 77 & 2 & 64 & 23 & 349 \\
Can & 24 & 56 & 30 & 114 & 5 & 64 & 35 & 328 \\
Ant & 38 & 17 & 18 & 21 & 0 & 17 & 10 & 121 \\
Sam & 26 & 7 & 5 & 17 & 1 & 10 & 13 & 79 \\
Mer & 20 & 17 & 5 & 16 & 0 & 3 & 16 & 77 \\
Tra & 13 & 4 & 2 & 3 & 0 & 3 & 5 & 30 \\
$\Sigma$ & 302 & 468 & 202 & 386 & 13 & 299 & 176 & 1,846 \\
\hline
\end{tabular}

Cs: Capsize, Cl: Collision, Fr: Fire, Gr: Grounding, Sl: Ship Loss, Ds: Dangerous Situation, Ot: Other, Ist: Istanbul, Izm: Izmir, Can: Canakkale, Ant: Antalya, Sam: Samsun, Mer: Mersin, Tra: Trabzon 
The distribution of accident types in seven different regions is shown in Figure 2. More accidents occurred in Istanbul, Çanakkale and İzmir regions than in other regions. In addition, collision accidents in Istanbul, grounding accidents in Çanakkale and capsize accidents in İzmir are more common than other accident types.

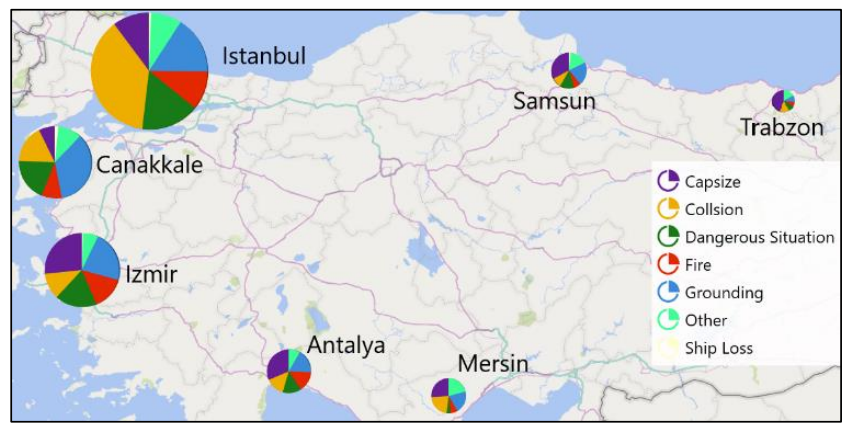

Figure 2. Types of accidents occurring in accident regions

\subsection{Correspondence analysis}

Different methods have been used in the investigation of accidents in the literature. We prefer correspondence analysis to determine the relationship between accident types and accident regions because of successful applications of correspondence analysis in the literature, especially in accident investigations. For example, Das and Sun stated in their study on vehicle crash that correspondence analysis is useful to determine the most effective crash countermeasures [36]. Li et al. showed that correspondence analysis is an appropriate technique in determining the factors causing fire accidents [37]. Lu et al. investigated the associations between fatality levels and influence factors that involve place, cause, time of day, month, year and province by using correspondence analysis [38]. Natarajan et al. showed that correspondence analysis can be a valid tool to analyze the complex nature of road accidents by correlating all necessary variables [39]. Das et al. emphasized that it is an advantage that Correspondence analysis does not require assumptions in determining the important factors causing accidents. In the same study, it was emphasized that correspondence analysis helps to present the relationship of variable categories in twodimensional space [40]. By examining reports on fatal pedestrian crashes in France, the relationships between different criteria were defined by multiple correspondence analysis [41]. In another study on occupational accidents, the data obtained from employees in various sectors were analyzed by multiple correspondence analysis [42].

Correspondence analysis has also been used in studies on marine accidents. There are quite a limited number of academic studies on the investigation of marine accidents with this method. For example, based on ships' AIS and accident data, ship accidents in Norwegian waters were analyzed using the cohesion analysis method [43]. Multiple Correspondence Analysis was conducted to analyze human and organizational factors in ship collisions [44].

Correspondence analysis is used to examine the relationship between categorical variables. Another reason for choosing correspondence analysis is that it visualizes this relationship in two-dimensional space. Correspondence analysis is a statistical method used in different fields rather than accidents in the literature. Multiple correspondence analysis, which deals with the relationship between more than two categorical variables, was used such as in tourism research [45], in the process of selecting personnel in the maritime sector [46], regarding the causes of occupational accidents by sectors [47] etc.

Correspondence analysis is a method of data analysis to graphically represent tabular data [48]. The term "correspondence analysis" was first proposed by JP Benzecri in 1962. Correspondence analysis was originally proposed as an inductive method for analyzing linguistic data [49]. It is used to determine the relationship between variables and to visualize them by reducing dimensions, based on frequency type data related to categorical variables in cross-tabulation. In this sense, it is similar to multidimensional scaling analysis. In correspondence analysis, apart from the multidimensional scaling analysis, specifically the relationship between categorical variables is visualized. In correspondence analysis, if two categorical variables are handled, it is called simple correspondence analysis, if more than two categorical variables are examined, it is called multiple correspondence analysis. It does not require any assumptions about the distribution of data [50].

In the first step of the correspondence analysis, row and column profiles are calculated. For example, where $r$ is the number of rows and $\mathrm{c}$ is the number of columns, first row profiles are calculated as $r_{1} ; \frac{n_{11}}{n_{1}}, \frac{n_{21}}{n_{1}}, \ldots, \frac{n_{c 1}}{n_{1}}$. Here the expression $\mathrm{n} 1$ shows the sum of the terms in the first column. Similarly, after the column profiles (ci) are calculated, the weights (mass) are found by proportioning each row sum to the whole sum. Column weights are also calculated similarly. With these weights, the importance of the profile in analysis is determined. The fit analysis uses the chi-square distance. Chisquare distance including (aij) row profile and (a.j) calculated as:

$$
d\left(i, i^{\prime}\right)=\sqrt{\sum_{j} \frac{\left(a_{i j}-a_{i^{\prime} j}\right)^{2}}{a_{. j}}}
$$

In fit analysis, the term inertia is used instead of the variance term. Total inertia is the total measure of the distance of the profile points to the center. Total inertia calculated as:

$$
\Lambda^{2}=\sum_{i} r_{i} d_{i}^{2}
$$

where, $\left(d_{i}\right)$ shows the chi-square distance of the point to the center and $\left(r_{i}\right)$ indicates the weight of the i. point.

Eigenvalues are calculated to find out how much of the total inertia is explained by the dimensions as follows:

$$
\lambda_{k}^{2}=\sum_{i} r_{i} f_{i k}^{2}
$$

where, $f_{i k}^{2}$ shows the the square of the coordinate of the point (i) and $\left(r_{i}\right)$ indicates the weight of the ith point. From here the contribution of ith point to kth dimension is calculated as follows:

$$
c a_{i k}=\frac{r_{i} f_{i k}^{2}}{\lambda_{k}^{2}}
$$

This value shows how much of inertia in kth dimension is explained by ith point. 


\section{FINDINGS AND RESULTS}

Correspondence analysis findings examining the relationship between accident zones and accident types are shown in Table 2.

Table 2. Correspondence analysis summary table

\begin{tabular}{|c|c|c|c|c|c|c|c|c|}
\hline D & SV & In & Chi & Sig. & \multicolumn{2}{|c|}{ Prop of In. } & \multicolumn{2}{|c|}{ Con Sing V } \\
\hline & & & & & $\overrightarrow{\text { Acc }}$ & Cum & Sd & Cor \\
\hline 1 & .320 & .103 & & & .607 & .607 & .022 & .105 \\
\hline 2 & .219 & .048 & & & .282 & .890 & .023 & \\
\hline 3 & .132 & .017 & & & .103 & .992 & & \\
\hline 4 & .034 & .001 & & & .007 & .999 & & \\
\hline 5 & .008 & .000 & & & .000 & 1.000 & & \\
\hline 6 & .007 & .000 & & & .000 & 1.000 & & \\
\hline$\Sigma$ & & .169 & 313.893 & $.000^{\mathrm{a}}$ & 1.000 & 1.000 & & \\
\hline & & & a. $36 \mathrm{c}$ & rees & freedon & & & \\
\hline
\end{tabular}

D: Dimension, SV: Singular Value, In: Inertia, Chi: Chi Square, Prop of In:

Proportion of Inertia, Con Sing V: Confidence Singular Value, Acc:

Accounted for, Cum: Cumulative, Sd: Standard Deviation, Cor: Correlation.

When Table 2 is examined, it is seen that there is a statistically significant relationship between regions (row variable) and accident types (column variable) $(\chi 2(36)$ $=313,893, \mathrm{p}<0.01)$. It is also determined that $60.7 \%$ of the total inertia is explained by the first dimension and $28.2 \%$ by the second dimension. Thus, two dimensions can explain $89 \%$ of the total inertia.

In Table 3, mass of row variables, and in Table 4, mass of column variables, coordinates in two-dimensional space and the inertia they explain are given.

Table 3. Mass, coordinates and explained inertia values of row variables

\begin{tabular}{ccccc}
\hline Region & Mass & \multicolumn{2}{c}{ Score in Dimension } & Inertia \\
\hline & & 1 & 2 & \\
Canakkale & .177 & -.057 & .923 & .034 \\
Izmir & .188 & .622 & .090 & .029 \\
Mersin & .047 & .753 & -.655 & .019 \\
Samsun & .043 & .927 & -.101 & .015 \\
Trabzon & .016 & 1.114 & -.918 & .010 \\
Antalya & .065 & .715 & -.327 & .014 \\
İstanbul & .464 & -.530 & -.234 & .047 \\
Active Total & 1.000 & & & .169 \\
\hline
\end{tabular}

As seen in Table 3, 46.4\% of the total accidents occurred in Istanbul, $18.8 \%$ in Izmir and $17.7 \%$ in Çanakkale. While this rate remained at $6.5 \%$ in Antalya, it was below 5\% in Mersin, Samsun and Trabzon.

According to the result obtained from Correspondence Analysis, the number of accidents that occur is affected by the regions where the accidents occur. The relatively high number of accidents in Istanbul is due to the traffic density and geographical structure of the Istanbul Strait. Therefore, this finding is in line with the priori expectation.

As can be seen, approximately $83 \%$ of the seven different types of accidents that occurred in seven regions during 16 years occurred in Istanbul, Izmir and Çanakkale. However, it is seen that most of the total variability in the number of accidents was explained by Istanbul $(0.047)$, followed by Çanakkale (0.034).

This finding shows that Istanbul and Çanakkale differ in some accident types. Although the number of accidents in İzmir is higher than Çanakkale, the reason why the variation explained by İzmir is lower than Çanakkale and İstanbul is the more balanced distribution of number of accident numbers among accident types in İzmir.

Table 4. Mass, coordinates and explained inertia values of column variables

\begin{tabular}{ccccc}
\hline Accident & Mass & \multicolumn{2}{c}{ Score in Dimension } & Inertia \\
\hline & & 1 & 2 & \\
Capsizes & .168 & .982 & -.539 & .063 \\
Collision & .252 & -.772 & -.414 & .058 \\
Fire & .109 & .063 & -.020 & .006 \\
Grounding & .208 & .116 & .687 & .023 \\
Ship Loss & .007 & -.183 & 1.239 & .003 \\
Dangerous Sit. & .161 & -.104 & .324 & .007 \\
Other & .095 & .175 & -.068 & .009 \\
Active Total & 1.000 & & & .169 \\
\hline
\end{tabular}

As seen in Table $4,25 \%$ of the total accidents are collision, $20.8 \%$ are grounding, $16.8 \%$ are capsize, $16.1 \%$ are dangerous situation, $10.9 \%$ are fire, $9.5 \%$ are other and $0.7 \%$ are ship loss. As can be seen, approximately $79 \%$ of the seven different types of accidents that occurred in the seven regions during 16 years are collision, grounding, capsize and dangerous situation. However, it is determined that the total variation in the number of accidents is largely explained by capsize $(0.063)$, followed by collision $(0.058)$. This finding shows that capsize and collision accidents differ in some regions.

Regions in Figure 3, accident types in Figure 4, regions and accident types in Figure 5 are shown in two-dimensional space. In the figures, the fact that the variable categories are distant from each other indicates that they show different characteristics, while being close indicates that they are related or show similar characteristics.

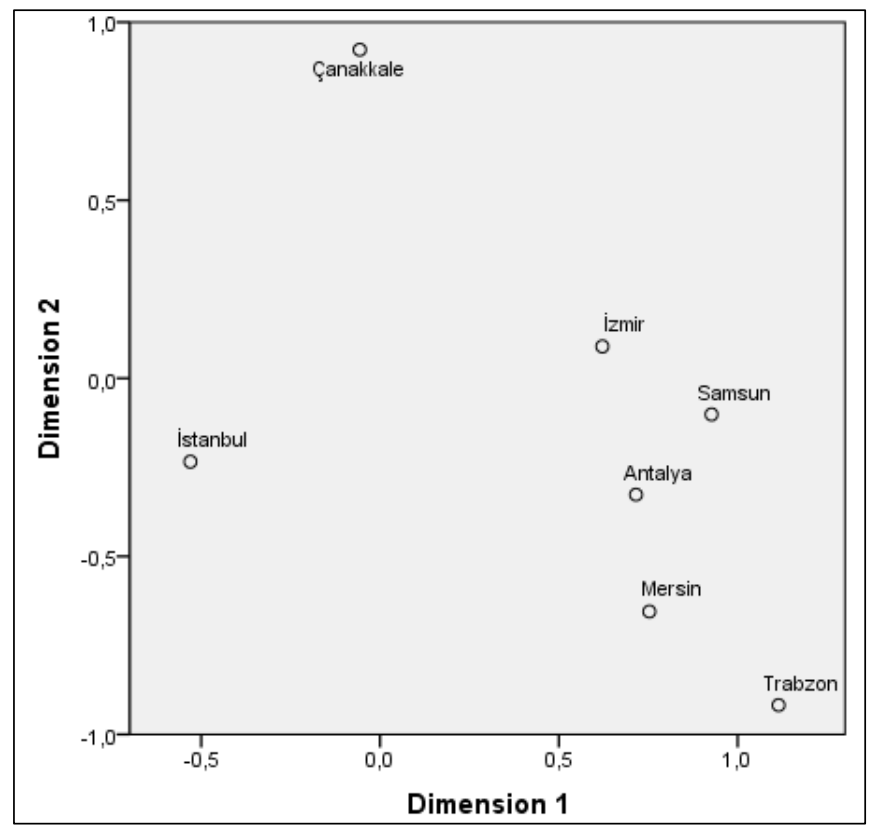

Figure 3. Relationship between regions according to number of accidents

When Figure 3 is examined, it is seen that Istanbul, Çanakkale and partially İzmir are located separately from each other and from the other four regions. This situation shows that the accident characteristics in these three regions are different. Samsun, Antalya, Mersin and Trabzon show similar characteristics in terms of accident types. 


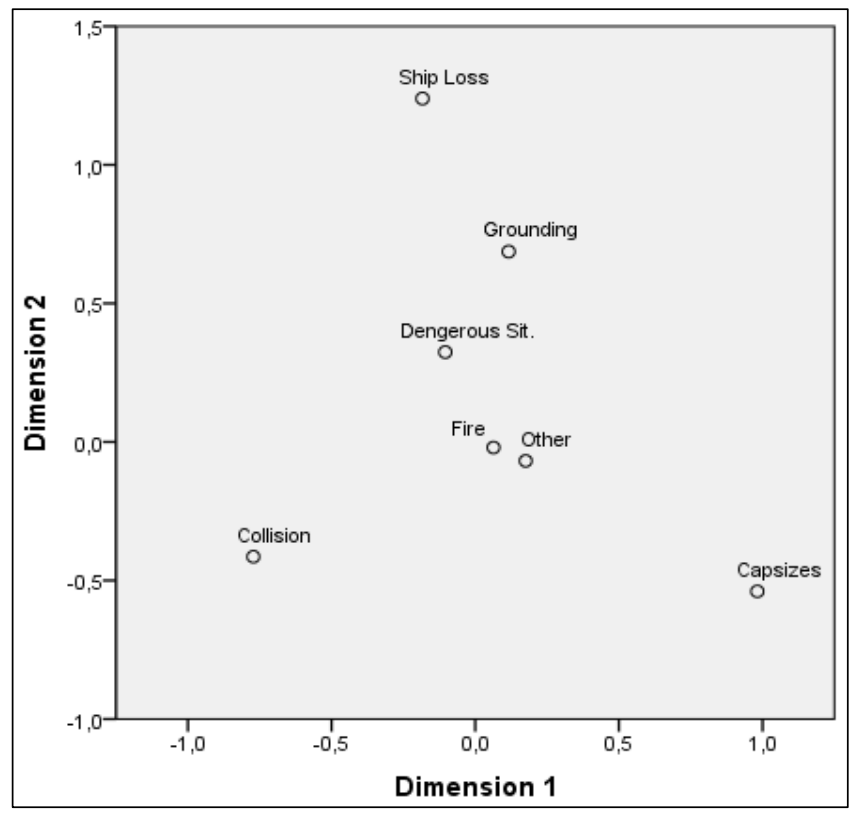

Figure 4. Relationship between accident types according to the number of accidents

When Figure 4 is examined, it is seen that Capsizes and Collision accidents are located differently from other accidents. Ship loss, grounding, dangerous sit., fire and other accidents show similar characteristics in the context of accident regions.

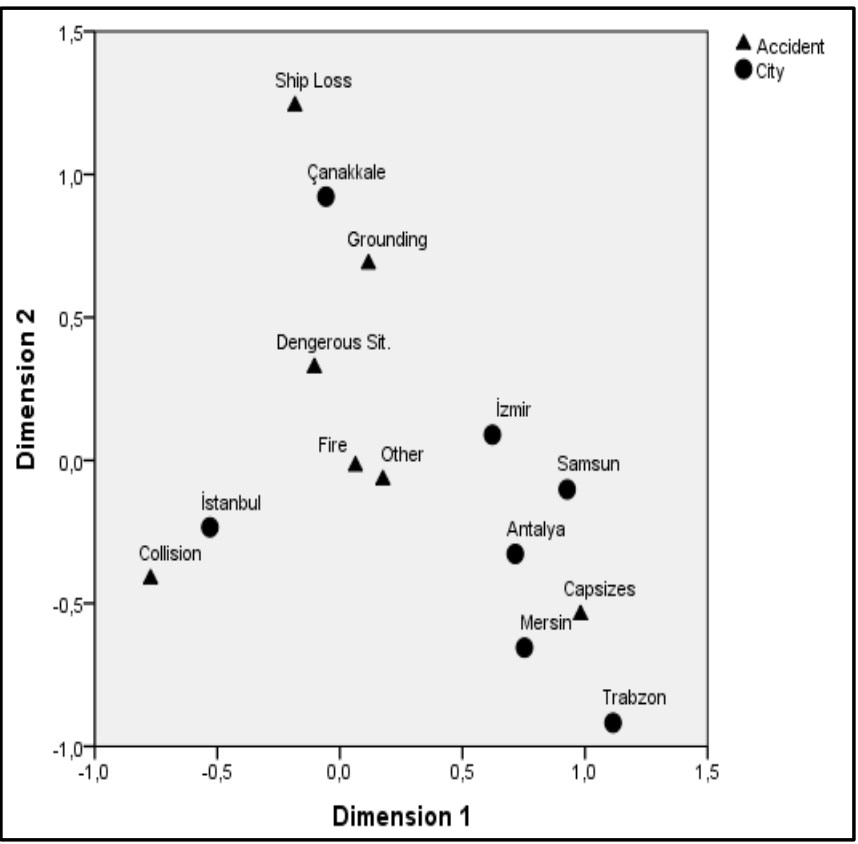

Figure 5. Relationship between accident regions and accident types according to the number of accidents

Finally, when Figure 5 is examined, it is seen that collision in Istanbul, Grounding and Ship Loss in Çanakkale, capsizes in Samsun, Antalya, Mersin and Trabzon, Fire and Other in İzmir are types of accidents that differentiate these regions. From this point of view, it can be said that accident areas are divided into 4 different groups as Istanbul, Çanakkale, İzmir and other regions (Samsun, Antalya, Mersin, Trabzon) as accident characteristics.

The high number of collision accidents in Istanbul and grounding accidents in Çanakkale can be attributed to the different geographical and meteorological characteristics of these two straits and the use of the straits in different shapes and densities. Due to the fact that the Bosphorus passes through the middle of a mega city, the presence of a large number of domestic vehicles and passenger lines connecting the two sides of the Strait increases the risk of conflict. As a matter of fact, the results of previous studies in the region also support this finding [51-53].

In the Dardanelles, it can be said that grounding accidents are more common due to sharp curves such as Nara Cape and sea currents from north to south. The reason for the high number of capsize and grounding accidents in the Izmir Region can be explained by the occasional excessive waves and winds in the Aegean Region. Since other regions are located in the Mediterranean and Black Sea, considering that these seas are open seas, it is estimated that the capsizing of the ships occurs as a result of taking water due to extreme waves and weather events.

In Figure 6, the relationship between accident regions and accident types is examined with the association plot. Association plot also supports the findings in Figure 5. The rectangles above the horizontal line drawn for each accident type in the graph indicate that the specified accident type is seen more in the region, and the accident types below the line are relatively less common in the region. When the plot is examined, it is noticed that accidents are seen more in Istanbul, Çanakkale and İzmir regions respectively, collision in Istanbul, grounding in Çanakkale and capsize in İzmir region are common.

According to Figure 6, capsizing is more common in regions located in open seas and in İzmir region. In addition, four of the seven different accident types are in imminent in the vicinity of Çanakkale region. Therefore, it can be considered that Çanakkale is generally a risky region in terms of marine accidents.

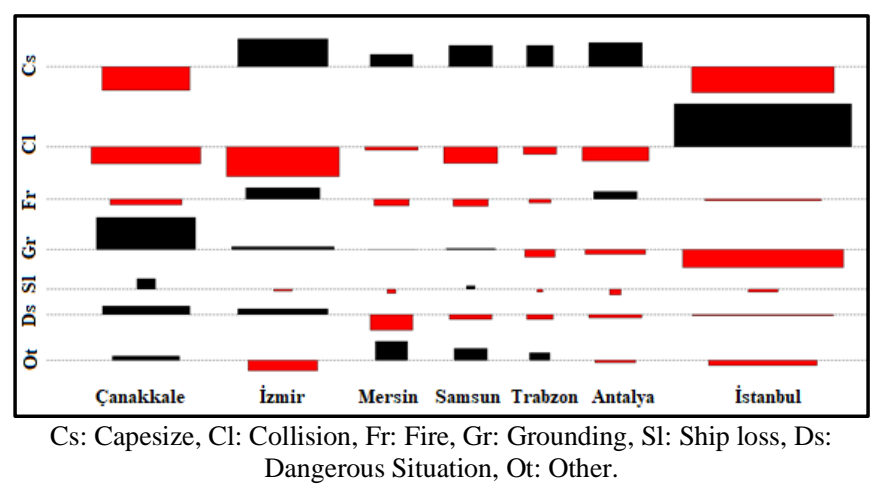

Figure 6. Association plot of accident types and regions

Collision, grounding and capsize account for more than $60 \%$ of total accidents. These accidents are affected by the characteristics of the region. These accidents are related to traffic density and meteorological and oceanographic features of the regions. However, apart from the regional characteristics, these accidents are also based on different reasons. Collision accidents may result from traffic density as well as violations of navigational regulations. Grounding accidents can occur due to machine failure. Capsize accidents are usually related to improper loading of ships and failure to secure cargo.

As can be seen, different accident types are intensified in different regions. Based on this relationship, measures to be 
taken regarding maritime accidents are possible by prioritizing resources. Prevention and response to marine accidents is under the authority of Directorate General of Coastal Safety. Coastal Safety has many different types and numbers of vehicles and equipments in its inventory regarding the response to accidents. Table 5 shows the inventory of vehicles allocated to regions. According to the table, it is understood that these vehicles are distributed in proportion to the number of accidents. Due to the very low accident rates and risks in other regions, it is thought that there is no vehicle in these areas yet. In addition, since the General Directorate of Coastal Safety was first established to intervene in marine accidents in the region consisting of the Istanbul-Çanakkale Straits and the Marmara Sea, it can be said that the resources are mostly located in this region.

Table 5. Inventory distribution of directorate general of coastal safety [54]

\begin{tabular}{cccccc}
\hline & Ist & Can & Izm & Ot & $\boldsymbol{\Sigma}$ \\
\hline Tug & 8 & 7 & 4 & - & 19 \\
Pilot boat & 9 & 6 & 3 & - & 18 \\
Fast rescue boat & 5 & 1 & 1 & - & 7 \\
Service boat & 5 & - & - & - & 5 \\
Lighter & 1 & - & 1 & - & 2 \\
Rigid-hulled inflatable boat & 2 & - & - & - & 2 \\
Search and rescue vessel & 1 & - & - & - & 1 \\
Oil Recovery Vessel & 1 & - & - & - & 1 \\
Barge & 5 & - & 1 & - & 6 \\
Floating crane & 1 & - & - & - & 1 \\
Barrier laying boat & 1 & 1 & - & - & 2 \\
Floating facility & - & - & 1 & - & 1 \\
Total & 39 & 15 & 11 & 0 & 65 \\
\hline
\end{tabular}

Ist: Istanbul, Can: Canakkale, Izm: Izmir, Ot: Other

In Figure 7, the rates of accidents that occurred in the regions and the resources allocated to the regions are compared. Considering the magnitude of the risks, it can be said that there is a balanced resource distribution in the regions where Coastal Safety serves and where accidents frequently occur. Resources are somewhat lower in İzmir compared to the accident rate. However, as international maritime traffic occurs in the Istanbul and Çanakkale Regions, it can be considered normal to allocate more resources in these regions.

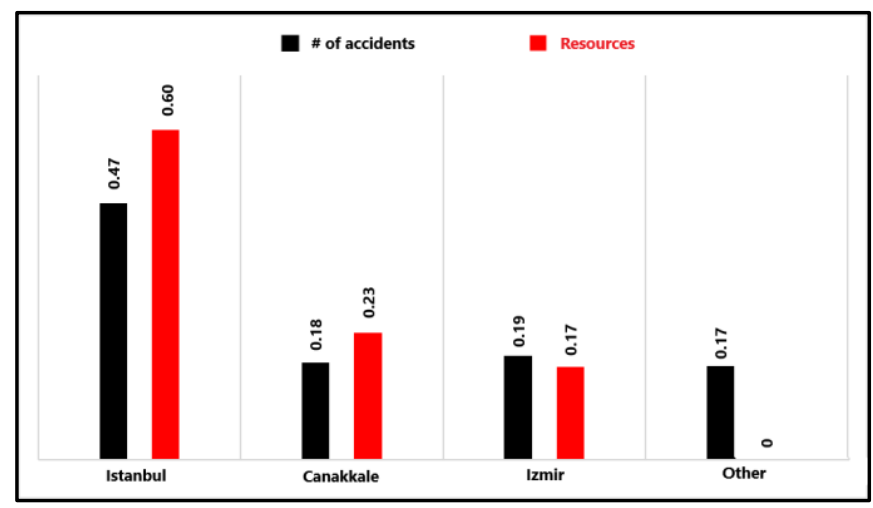

Figure 7. Marine accidents and resource distribution by regions

\section{CONCLUSION}

Despite the implementation of measures for marine accidents in recent years, marine accidents continue to occur.
Because the root cause of the vast majority of these accidents is human error [18, 44, 55-58]. Thus, reactive approaches to accidents are important in reducing the effects of accidents. In other words, resource allocation should be made considering the possibility of accidents occurring in the regions. However, proactive approaches to prevent accidents will be much more effective in preventing losses that may occur. As a result of this research, based on the relationship between accident areas and accident types, proactive approaches can be applied by correct allocation of resources regarding the types of accidents expected in the accident regions. For example, since collision accidents mostly occur in Istanbul, studies should be done to improve the existing traffic in this region. On the other hand, since grounding accidents are generally seen in the Canakkale region, meteorological conditions should also be considered in cruise planning.

This study focuses on the relationship between marine accident types and accident areas. In this context, it has been investigated whether the distribution of marine accident response vehicles and equipment is appropriate in the regions. A statistically significant relationship was found between the accident region and the accident type. This finding is consistent with the study [28]. Therefore, the a priori anticipation that resource allocation should be made by considering accident types has been confirmed. According to the findings of the study, it is important to allocate additional resources in Mersin, Antalya, Samsun and Trabzon regions, where there are no resources yet, especially for intervention in capsize accidents.

Although previous studies were carried out on certain marine areas, this is the first study addressing all marine accidents occurring in the territorial waters of Turkey. It is determined that collisions are more common in the Istanbul region compared to other accident types. It can be said that the factors mentioned in the previous studies [25-27] were effective in the emergence of this result. In Istanbul, collision accidents are more common than other accident types. Although the strait is controlled by the traffic separation scheme and Vessel Traffic System (VTS) in accordance with COLREG 1972, collision accidents continue to occur due to the presence of domestic lines and the natural structure of the Bosphorus.

Similarly, in accordance with the previous studies [22, 23], it is seen that the geographical structure of the Dardanelles and the current currents are also effective in the occurrence of grounding accidents.

The most important challenge encountered in the study is that the marine accident data are not detailed enough. However, a large number of international conventions, codes, guides, standards and circulars have been published by IMO in order to report marine accidents in accordance with a certain standard [59]. In order to analyze the causes of marine accidents better, the data related to the accidents should be recorded in accordance with the standards published by IMO [60].

Available data limit the scope of the study to Turkish territorial waters, but this study can be extended to different accident types and different regions around the world.

\section{ACKNOWLEDGMENT}

The authors thank the General Directorate of Coastal Safety for their support. 


\section{REFERENCES}

[1] Zhang, D., Yan, X.P., Yang, Z.L., Wall, A., Wang, J. (2013). Incorporation of formal safety assessment and Bayesian network in navigational risk estimation of the Yangtze River. Reliability Engineering \& System Safety, 118: 93-105. https://doi.org/10.1016/j.ress.2013.04.006

[2] ATSB. (2019). Australian Transport Safety Bureau. https://www.atsb.gov.au/, accessed on Sep. 17, 2019.

[3] DMAIB. (2019). Danish Maritime Accident Investigation Board. https://www.dmaib.com/, accessed on Sep. 17, 2019.

[4] MIT. (2019). Minister of Infrastructures and Transport of Italy. http://www.mit.gov.it/en, accessed on Sep. 17, 2019.

[5] JTSB. (2019). The Japan Transport Safety Board. https://www.mlit.go.jp/jtsb/english.html, accessed on Sep. 17, 2019.

[6] MNZ. (2019). Maritime New Zealand. https://www.maritimenz.govt.nz/, accessed on Sep. 17, 2019.

[7] DSB. (2019). Dutch Safety Board. https://www.onderzoeksraad.nl/en/, accessed on Sep. 17, 2019.

[8] EMSA. (2019). European Maritime Safety Agency. http://www.emsa.europa.eu/about.html, accessed on Sep. 17, 2019.

[9] MAIB. (2017). Annual Report. https://www.gov.uk/government/publications/maibannual-report-2017, accessed on Sep. 17, 2019.

[10] IIMS. (2019). Mariners Alerting and Reporting Scheme. https://www.iims.org.uk/mariners-alerting-reportingscheme-mars/, accessed on Sep. 17, 2019.

[11] TCUAB. (2019). Republic of Turkey Ministry of Transport and Infrastructure. http://aakkm.udhb.gov.tr/, accessed on Sep. 17, 2019.

[12] Mazaheri, A., Montewka, J., Kujala, P. (2016). Towards an evidence-based probabilistic risk model for shipgrounding accidents. Safety Science, 86: 195-210. https://doi.org/10.1016/j.ssci.2016.03.002

[13] Goerlandt, F., Kujala, P. (2011). Traffic simulationbased ship collision probability modeling. Reliability Engineering and System Safety, 96: 91-107. https://doi.org/10.1016/j.ress.2010.09.003

[14] Mou, J.M., van der Tak, C., Ligteringen, H. (2010). Study on collision avoidance in busy waterways by using AIS data. Ocean Engineering, 37: 483-490. https://doi.org/10.1016/j.oceaneng.2010.01.012

[15] Faghih-Roohi, S., Xie, M., Ng, K.M. (2014). Accident risk assessment in marine transportation via Markov modelling and Markov Chain Monte Carlo simulation. Ocean Engineering, 91: 363-370. https://doi.org/10.1016/j.oceaneng.2014.09.029

[16] Montewka, J., Goerlandt, F., Kujala, P. (2014). On a systematic perspective on risk for formal safety assessment (FSA). Reliability Engineering and System Safety, 127:

77-85. https://doi.org/10.1016/j.ress.2014.03.009

[17] Zaman, M.B., Kobayashi, E., Wakabayashi, N., Maimun, A. (2015). Risk of navigation for marine traffic in the Malacca strait using AIS. Procedia Earth and Planetary Science, $\quad 14: \quad 33-40$ https://doi.org/10.1016/j.proeps.2015.07.082

[18] Luo, M., Shin, S.H. (2019). Half-century research developments in maritime accidents: Future directions. Accident Analysis and Prevention, 123: 448-460. https://doi.org/10.1016/j.aap.2016.04.010

[19] Geçili, D. (2017). Maritime pilots in straits of the Ottoman Empire. KTÜ Sosyal Bilimler Dergisi, 7(13): 111-122.

[20] Efes, K.Ö. (2006). Özel Duyarlı Deniz Alanları ve Türk Boğazlar Bölgesi. İstanbul: T.C. İstanbul Üniversitesi Deniz Bilimleri ve İşletmeciliği Enstitüsü, Yüksek Lisans Tezi.

[21] Cömert, A. (2013). Developing a navigational model for the Turkish straits. PhD Thesis. İstanbul: İstanbul Technical University, Graduate School of Science Engineering and Technology.

[22] Bolat, P., Yongxing, J. (2013). Risk assessment of potential catastrophic accidents for transportation of special nuclear materials through Turkish Straits. Energy Policy, 56: 126-135. https://doi.org/10.1016/j.enpol.2012.12.010

[23] Sezgin, M. (2007). Deniz Kirliliğine Neden Olabilecek Deniz Kazalarında Sahil Güvenlik Birimlerinin Koordinatör Rolü ve Kriz Yönetimi (Doctoral dissertation, Yüksek Lisans Tezi. Dokuz Eylül Üniversitesi).

[24] Taşlıgil, N. (2004). İstanbul Boğazı'nın ulaşım coğrafyası açısından önemi.

[25] Salihoğlu, E. (2017). İstanbul Boğazı Denizyolu Taşımacıllı̆ııın İş Güvenliği Açısından İncelenmesi. Kocaeli: Kocaeli Üniversitesi, Fen Bilimleri Enstitüsü, Yüksek Lisans Tezi.

[26] Koldemir, B. (2006). İstanbul Boğazı Trafiğinde Seyir Güvenliği Sorunu Olan Bölgelerin Belirlenmesi İçin Bir Yöntem. Pamukkale Üniversitesi Mühendislik Fakültesi Mühendislik Bilimleri Dergisi, 12(1): 51-57.

[27] Atasoy, C. (2007). İstanbul Boğazı'nda Yerel Trafiğin İncelenmesi. Doctoral dissertation, Fen Bilimleri Enstitüsü.

[28] Ece, J.N. (2012). Analysis of ship accidents in the strait of Istanbul. Dokuz Eylül Üniversitesi, Denizcilik Fakültesi Dergisi, 4(2): 1-25.

[29] Şahin, O.A. (2016). İzmit Körfezi Deniz Trafiğinin Iwrap Model Kullanılarak İncelenmesi (Doctoral dissertation, Fen Bilimleri Enstitüsü).

[30] İnan, A. (2011). İskenderun Körfezi' nde Petrol Kirliliğinin Modellenmesi. Journal of the Faculty of Engineering \& Architecture of Gazi University, 26(2): 471-478.

[31] IMO, (2019). Convention on the International Regulations for Preventing Collisions at Sea. http://www.imo.org/en/About/conventions/listofconvent ions/pages/colreg.aspx, accessed on Sep. 17, 2019.

[32] Psarros, G., Skjong, R., Eide, M.S. (2010). Underreporting of maritime accidents. Accident Analysis and Prevention, 42: 619-625. https://doi.org/10.1016/j.aap.2009.10.008

[33] Hassel, M., Asbjørnslett, B.E., Hole, L.P. (2011). Underreporting of maritime accidents to vessel accident databases. Accident Analysis and Prevention, 43(6): 2053-2063. https://doi.org/10.1016/j.aap.2011.05.027

[34] Mou, J., Chen, P., He, Y., Yip, T.L., Li, W., Tang, J., Zhang, H. (2019). Vessel traffic safety in busy waterways: A case study of accidents in Western Shenzhen port. Accident Analysis and Prevention, 123: 461-468. https://doi.org/10.1016/j.aap.2016.07.037 
[35] DGMM. (2019). Director General of Merchant Marine. https://atlantis.udhb.gov.tr/istatistik/diger_deniz_kazalar i.aspx, accessed on Sep. 17, 2019.

[36] Das, S., Sun, X. (2016). Association knowledge for fatal run-off-road crashes by Multiple. IATSS Research, 39: 146-155. https://doi.org/10.1016/j.iatssr.2015.07.001

[37] Li, G., Lu, S., Zhang, H., Lo, S. (2013). Correspondence analysis on exploring the association between fire causes and influence factors. Procedia Engineering, 62: 581-591. https://doi.org/10.1016/j.proeng.2013.08.103

[38] Lu, S., Mei, P., Wang, J., Zhang, H. (2012). Fatality and influence factors in high-casualty fires: A correspondence analysis. Safety Science, 50: 1019-1033. https://doi.org/10.1016/j.ssci.2011.12.006

[39] Natarajan, P., Sivasankaran, S.K., Balasubramanian, V. (2020). Identification of contributing factors in vehicle pedestrian crashes in Chennai using multiple correspondence analysis. Transportation Research Procedia, 48: 3486-3495. https://doi.org/10.1016/j.trpro.2020.08.104

[40] Das, S., Avelar, R., Dixon, K., Sun, X. (2018). Investigation on the wrong way driving crash patterns using multiple correspondence analysis. Accident Analysis and Prevention, 111: 43-55. https://doi.org/10.1016/j.aap.2017.11.016

[41] Fontaine, H., Gourlet, Y. (1997). Fatal pedestrian accidents in France: A Typological Analysis. Accident Analysis \& Prevention, 29(3): 303-312. https://doi.org/10.1016/S0001-4575(96)00084-X

[42] Niza, C., Silva, S., Lima, M.L. (2008). Occupational accident experience: Association with workers' accident explanation and definition. Safety Science, 46(6): 959971. https://doi.org/10.1016/j.ssci.2007.11.015

[43] Bye, R.J., Aalberg, A.L. (2018). Maritime navigation accidents and risk indicators: An exploratory statistical analysis using AIS data and accident reports. Reliability Engineering and System Safety, 176: 174-186. https://doi.org/10.1016/j.ress.2018.03.033

[44] Chauvin, C., Lardjane, S., Morel, G., Clostermann, J.P., Langard, B. (2013). Human and organisational factors in maritime accidents: Analysis of collisions at sea using the HFACS. Accident Analysis and Prevention, 59: 2637. https://doi.org/10.1016/j.aap.2013.05.006

[45] Richards, G., van der Ark, L.A. (2013). Dimensions of cultural consumption among tourists: Multiple correspondence analysis. Tourism Management, 37: 71 76. https://doi.org/10.1016/j.tourman.2013.01.007

[46] Koutra, G., Barbounaki, S., Kardaras, D., Stalidis, G. (2017). A multicriteria model for personnel selection in maritime industry in Greece. In 2017 IEEE 19th Conference on Business Informatics (CBI), 1: 287-294.

[47] Williamson, A.M., Feyer, A.M., Cairns, D.R. (1996).
Industry differences in accident causation. Safety Science, 24(1): 1-12. https://doi.org/10.1016/S09257535(96)00025-2

[48] Greenacre, M. (2017). Correspondence Analysis in Practice. CRC press.

[49] Murtagh, F. (2005). Correspondence Analysis and Data Coding with Java and R. CRC Press.

[50] Kılıç, A.F. (2016). Uyum Analizi (Correspondence Analysis). YBS Ansiklopedi, 1-20.

[51] Korçak, M. (2015). İstanbul Boğazı'nda kimyasalların deniz yolu ile taşınması sırasında meydana gelen kazaların yönetimi (Doctoral dissertation, Doktora Tezi, Gazi üniversitesi Fen Bilimleri Enstitüsü).

[52] Altan, Y.C. (2017). Analysis and Modeling of Maritime Traffic and Ship Collision in the Strait of Istanbul based on Automatic Vessel Tracking System. Graduate Program in Civil Engineering, Boğaziçi University, p77.

[53] Görçün, Ö.F., Burak, S.Z. (2015). Formal Safety Assessment for Ship Traffic in the Istanbul Straits. Procedia - Social and Behavioral Sciences, 207: 252-261.

[54] DGCS. (2020). Directorate General of Coastal Safety, Istanbul.

[55] Yıldırım, U. (2016). Deniz Kazalarının İnsan Faktörleri Analiz ve Sinıflandirma Sistemi (HFACS) ile İncelenmesi. Trabzon: Karadeniz Teknik Üniversitesi, Fen Bilimleri Enstitüsü, Doktora Tezi.

[56] Erol, S. (2009). Tekne Sigorta Priminin Belirlenmesinde Risk Unsuru Olarak İnsan Faktörünün Değerlendirilmesi. Trabzon: Karadeniz Teknik Üniversitesi, Fen Bilimleri Enstitüsü, Yüksek Lisans Tezi.

[57] Ung, S.T. (2018). Human error assessment of oil tanker grounding. Safety Science, 104: 16-28. https://doi.org/10.1016/j.ssci.2017.12.035

[58] Yıldırım, U., Başar, E., Uğurlu, Ö. (2019). Assessment of collisions and grounding accidents with human factors analysis and classification system (HFACS) and statistical methods. Safety Science, 119: 412-425. https://doi.org/10.1016/j.ssci.2017.09.022

[59] IMO. (2008). Casualty-Related Matters Reports on Marine Casualties and Incidents. London: IMO.

[60] IMO. (2014). Model Course 3.11 Safety Investigation into Marine Casualties and Marine Incidents. London: International Maritime Organization.

\section{NOMENCLATURE}

$\chi^{2} \quad$ Chi-square

$\mathrm{d}_{\mathrm{i}} \quad$ Chi-square distance

$\Lambda^{2}$ Total inertia

$\lambda$ Eigenvalue 